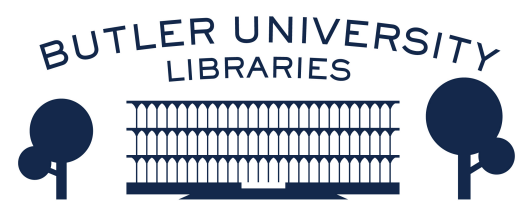

Journal of Hindu-Christian Studies

Volume 21

Article 14

January 2008

\title{
Viewpoint: More or Deeper? What Should be Next in (My) Hindu- Christian Study
}

Francis X. Clooney

Follow this and additional works at: https://digitalcommons.butler.edu/jhcs

Part of the Religion Commons

\section{Recommended Citation}

Clooney, Francis X. (2008) "Viewpoint: More or Deeper? What Should be Next in (My) Hindu-Christian Study," Journal of Hindu-Christian Studies: Vol. 21, Article 14.

Available at: https://doi.org/10.7825/2164-6279.1413

The Journal of Hindu-Christian Studies is a publication of the Society for Hindu-Christian Studies. The digital version is made available by Digital Commons @ Butler University. For questions about the Journal or the Society, please contact cbauman@butler.edu. For more information about Digital Commons @ Butler University, please contact digitalscholarship@butler.edu. 


\title{
VIEWPOINT More or Deeper? What Should be Next in (My) Hindu-Christian Study
}

\author{
Francis X. Clooney, S.J. \\ Harvard Divinity School
}

RECENTLY I completed two books in the field of Hindu-Christian studies. The first is The Truth, the Way, the Life: Christian Commentary on the Three Holy Mantras of the Srivaisnava Hindus (Peeters Publishing). This project, for Catherine Cornille's new series of Christian commentaries on the sacred texts of nonChristian traditions, is heavily indebted to Vedanta Desika's $14^{\text {th }}$ century reading of the Tiru Mantra, Dvaya Mantra, and Carama Sloka. The second book is Beyond Compare: St. Francis de Sales and Sri Vedanta Desika on Loving Surrender to God (Georgetown University Press), an intensive double reading of Desika's Essence of the Three Holy Mysteries (Srimadrahasyatrayasara) along with de Sales' Treatise on the Love of God (Traité de l'Amour de Dieu). Both projects manifest my predilection for close reading, attention to commentary, and goal of writing from and after close reading, rather than simply in answer to questions formulated before the reading began. Both books will confirm, I hope, my belief that very interesting learning - perhaps the most interesting learning - occurs when we use every available scholarly resource in taking the text/s of another tradition to heart, immersing oneself in them, and on that basis learning eventually to re-read one's own tradition in the light of that other.

In both projects, I found that the realities of which the mantras and the Essence and Treatise speak are present in those texts. Reading them with spiritual attentiveness opens a way of sharing in the sentiments and practices of a more radical relationship to God. Beyond Compare is all about loving surrender to God - prapatti, abandonment - as a practice at the extreme reach of each tradition, both surpassing and fulfilling what each envisions its ordinary truths and values to be. The Truth, the Way, the Life is about the rather impossible state of mind that emerges when a Christian studies the three mantras carefully and takes them to heart even in relation to her or his own faith - recognizing the deep commitment to Narayana with Sri that is impossible for the Catholic, while at the same time finding in the mantras a way to hear and then utter anew fundamental Biblical prayers. Textual work, in this light, is not secondary research, simply about what others believe, utter, do; rather, learning across the boundaries of traditions becomes a rather intense form of firsthand experience. Hindu-Christian studies is a

Francis X. Clooney,S.J., is Parkman Professor of Divinity and Professor of Comparative Theology at Harvard Divinity School. His primary areas of scholarship are theological commentarial writings in the Sanskrit and Tamil traditions of Hindu India, and the developing field of comparative theology. Professor Clooney is the author of numerous articles and books, including Hindu God, Christian God (Oxford University Press, 2001), Divine Mother, Blessed Mother: Hindu Goddesses and the Virgin Mary (Oxford University Press, 2005), and Jesuit Postmodern: Scholarship, Vocation, and Identity in the 21st Century (Lexington Books, 2006). He has just completed two books: Beyond Compare: St. Francis and Sri Vedanta Desika on Loving Surrender to God (Georgetown University Press,', 2008), and The Truth, the Way, the Life: Christian Commentary on the Three Holy Mantras of the Srivaisnava Hindus (Peeters Publishing [Leuven], 2008). His current projects include an introductory volume on comparative theology, and a study of yoga and Jesuit spirituality. 
perfect site, I have learned yet again, for internal dialogue, interreligious lectio divina, and consequent contemplative practices.

While finishing these books, I also had occasion to teach two seminars at Harvard Divinity School: in the fall of 2007, one dedicated to the Brhadaranyaka Upanisad Bhasya of Sankara, and in the spring of 2008, another dedicated to the Yoga Sutras of Patanjali, read along with Vyasa's Bhasya and later commentaries. (In both we used translations, only consulting the Sanskrit.) Sankara's commentary is, among other things, a very intensely self-conscious act of teachingthrough-reading, as the master draws his readers ever more completely into the potentially explosive insights of the Upanisad, using every simple or arcane gloss, heated argument, and seeming digression, to clear the way for greater vulnerability to the Upanisad's core meaning. The Yoga Sutras, read with their commentaries, similarly engage, instruct, unsettle, and transform how the attentive reader sees her or his mind and body, and how life's processes and goals are to be articulated and lived.

Both seminars are part of a longer cycle I teach at HDS, "Reading Hindu Texts Interreligiously." This series is intended to show that even in the academic setting classic texts can and should be read at a slow pace: at most, one book a semester, rather than by the greatbook-a-week pace we have come to expect. When we read slowly, we realize that even slower is better, as we see more and more in the classic before us. In neither semester did we finish reading Sankara or the Yoga Sutras, since over the weeks of the course we were learning to read better and still more slowly. At each semester's end, we felt that we had barely begun our work. Both also confirmed, for me at least, the insight of my books: reading is a potent activity that demands very much from the reader drawn into the world of the text, as Hindu and Christian realities become proximate to one another in the very words before our eyes.

While neither seminar was an overtly religious event - we remained in the classroom, with all the constraints of academe, from syllabus to grades - we found that study did not respect fixed Hindu-Christian boundaries. Since both were also experiments in interreligious reading (with select pages from St. Augustine and Rabbinic texts in the first, and the Spiritual Exercises of Ignatius Loyola in the second), the seminars were at least incipiently acts of interreligious learning, wherein the learning practices and insights of each tradition intensify the other, leaving the reader somewhat literate in both, well read across the boundaries of the traditions.

So my writing projects and the seminars coalesced in highlighting challenges and hopes basic to our field. But on that very basis, a question has emerged for me: What ought my next major writing project be? I have been in academe long enough now, have been at the study of Hindu texts and comparative study for decades, have published enough, and have enough likely projects sitting on my shelves that I will in theory have no problem generating a next book project. But as I think about what to write next, in light of what we care about, several complications arise. First, is it worthwhile to repeat myself, taking up a similar project, another exegetical study, simply with some different texts? As is commonly observed, one may write the same book several times in a career, simply changing the title. This is not entirely bad, since there is always a tension between doing well, again, what one has already done before, or venturing into something new, where our expertise is less and the field more crowded with better scholarship - as if, for example, I were to take up a project related to the Yoga Sutras, a text that has been studied voluminously and in detail. Novelty can be fine, and pragmatically so when we have to justify a book proposal by indicating its important contribution to a field of study: But "progress" may not be the right word for readings that overlap with one another in increasing intensity, as if in one insight written, driven home, over and again, back and forth between Hindu and Christian sources. Notions of advancing knowledge, the answering of questions, getting the research done may not accurately catch what we need to be thinking about in a field where depth should be more important than quantities of learning. Rather than taking up new projects, perhaps we should go deeper into texts we have already read, further exploring the primary source materials that underlie the work we have 
already been doing. Both Hindu and Christian traditions tell us that person and practice matter more than quantity and novelty, and we must be careful lest the words we write obstruct the deeper learning essential to the flourishing of Hindu-Christian studies.

Since the practices of writing and reading highlight the need for competence, as I worry about my own capabilities I ought also to be thinking about the identity and expectations of my probable readers. What might be the hoped-for fruit of my next project, particularly as a contribution to Hindu-Christian studies? As I become ever more appreciative of the potency of study, and as I work my way back and forth between Hindu and Christian classics, I am aware of the complexity of the Hindu-Christian interaction, and the premium to be placed on the small community of scholars who work across the boundaries. The results become ever more intense and demanding; introductory texts and courses aside, our writing might well be conceived of as promising greater benefits but for a very small group of readers that is committed to this particular interreligious field of study. If so, do such readers need another book from me (or from you), when we have already agreed - over and again in our meetings, writing, teaching - that it is in a meditative intellectual practice, and not in quantity, that learning bears fruit? We might, after all, write no more, and simply re-read the books all of us have already written.

Or to put it another way: I need to write in accord with my current sense toward the hyphen in "Hindu-Christian Studies." (I thus echo, it seems, AK Ramanujan's famous insight, several decades ago, that he was the hyphen in IndoAmerican studies.) Increasingly, by a realization I surely share with many of the readers of this journal, our hyphen no longer marks simply a possible bridge between two fields of study that remain nearby but separate. Beyond the "Hindu" and the "Christian" lies a deeper mingling of two worlds that for us now define, some of the time, a single complex field. "Hindu-Christian studies," then, might better be thought of as also something such as "Hinduchristian Studies," from which arises, even for those of us (such as myself) who remain personally "just Christian" or "just Hindu," a vivid set of real questions that are not adequately reducible to either tradition, but rather are always indebted to both. If often enough faith outstrips theology, here it may be the case that theology and allied forms of academic study flourish in a hinduchristian site where faith has not yet found a home or voice. I'd like to think, for instance, that Beyond Compare, or my earlier Divine Mother, Blessed Mother, creates a place for academic and faith reflection that is inextricably indebted to both sides of the Hindu-Christian bond.

But in this situation, the audience will not be simply a few Hindus plus a few Christians, but rather a developing hinduchristian community. It is a community that needs to work together all the harder, because we need one another, because we need to make the case to a skeptical academic community that our decades of conversation and shared scholarship have created a new academic space of intrinsic merit, and because we need to convince both Christians and Hindus that our research is of religious and theological importance even to those who do not do comparative study.

Such are my thoughts as I reflect on the choices before me, whether to return to some familiar but only partly explored text, do a new translation, or attempt some historical retrieval, and to do any of these with a determination to write after and in light of my 30-plus years of reading Hindu and Christian texts together. Perhaps our reflective moments of hesitation will help us to be more like the great Christian and Hindu thinkers whose work we admire and study - women and men whose words were so often few, artful, and intense, never entirely here or there. 